\title{
Truck Sharing App Ekspedisi Jalur Pontianak - Sandai dengan Metode Location Based Service Berbasis Progressive Web App
}

\author{
Yus Sholva $^{\# 1}$, Haried Novriando ${ }^{\# 2}$, Steven ${ }^{\# 3}$

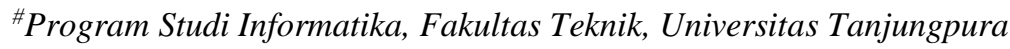 \\ Jl. Prof. Dr. H. Hadari Nawawi, Pontianak 78124 \\ ${ }^{1}$ sholvariza@untan.ac.id \\ 2hariedeinformatika.untan.ac.id \\ ${ }^{3}$ steven97@student.untan.ac.id
}

\begin{abstract}
Abstrak - Ekspedisi merupakan jasa pengiriman yang sangat dibutuhkan dikalangan pengiriman barang ketempat yang jauh, karena ekspedisi merupakan jasa yang mengirimkan barang sampai ditujuan dengan bertanggung jawab. Permasalahan ekspedisi ini khususnya area jalur Pontianak Sandai oleh orang yang ingin memakainya jasa ini, kesulitan mengetahui posisi truk ekspedisi yang beroperasi saat ini. Sehingga truk-truk yang melalui jalur Pontianak - Sandai dalam keadaan tidak bermuatan dan ini tidak efisien karena biaya perjalanan akan meningkat apabila barang yang mereka bawa sedikit. Tujuan penelitian ini untuk membangun aplikasi truck sharing pada jalur Pontianak Sandai dengan metode location based service (LBS) yang berbasis progressive web app (PWA). Pengimplementasian aplikasi ini, toko dapat memilih sendiri truk-truk ekspedisi mulai dari jarak yang terdekat dan rating, yang diberikan pihak toko lain sebelumnya. Aplikasi dibangung dengan menggunakan metode LBS dapat menampilkan titik-titik lokasi supir di sekitarnya dengan memanfaatkan GPS yang ada pada perangkat pengguna berdasarkan radius yang ditentukan oleh toko. Sedangkan penerapan PWA, bertujuan memudahkan pihak toko dan supir untuk mengakses aplikasi melalui semua perangkat seperti smartphone, PC, laptop, atau tablet. Perancangan sistem dibangun dengan menggunakan Unified Modelling Language (UML), untuk pengujian aplikasi dilakukan dengan dua cara, yaitu pengujian dengan metode Black Box dan Skala Likert. Hasil yang didapatkan dari pengujian Black Box adalah sistem dapat bekerja dengan LBS dan PWA sesuai yang diharapkan.
\end{abstract}

Kata kunci- Ekspedisi, GPS, Location Based Service, Progressive Web App, Truck Sharing

\section{Pendahuluan}

Jasa ekspedisi merupakan usaha yang ditujukan untuk mewakili kepentingan pemilik barang dalam mengurus semua kegiatan yang diperlukan bagi terlaksananya pengiriman dan penerimaan barang melalui transportasi. Jasa adalah setiap tindakan atau kinerja yang dapat ditawarkan satu pihak kepada pihak lain, yang dasarnya tidak berwujud dan tidak mengakibatkan kepemilikan sesuatu [1]. Perusahaan ekspedisi adalah suatu perusahaan yang bergerak dibidang pengiriman barang baik pengiriman melalui jalur darat, jalur air atau jalur udara. Umumnya perusahaan jasa ekspedisi menggunakan kendaraan transportasi berukuran besar, misalnya truk muatan, untuk melakukan pengiriman barang. Istilah lain yang berhubungan dengan jasa pengiriman barang adalah cargo dan logistik yang umumnya melayani wilayah yang lebih luas dan jauh seperti antar propinsi, antar negara dalam jumlah yang relatif banyak.

Terlebih lagi di masa pandemi covid-19 ini memberikan dampak yang cukup signifikan dalam jasa pengiriman barang. Industri kurir di Indonesia mengalami perkembangan yang sangat pesat karena adanya perubahan perilaku masyarakat untuk belanja online atau melalui ecommerce. Peningkatan belanja online terjadi karena masyarakat memilih untuk memenuhi kebutuhan melalui online, karena hal tersebut sesuai dengan peraturan kebijakan pemerintah untuk Work from Home (WFH).

Salah satu contoh kasus ekspedisi pribadi adalah layanan ekspedisi yang beroperasi pada rute atau jalur Kota Pontianak ke Sandai. Ekspedisi ini menggunakan kendaraan truk untuk membawa barang-barang dari Kota Pontianak menuju Sandai dan sebaliknya. Umumnya barang yang dibawa adalah seperti barang-barang elektronik, alat-alat dan bahan bangunan, barang drum berupa oli maupun yang kotak, barang furniture, barang karung-karungan seperti pakan ayam dan ikan. Pada saat ini pihak toko mengirimkan barang mereka dengan cara menghubungi via chat atau telepon kepada pihak supir untuk mengetahui lokasi ekspedisi.

Namun dalam memberikan layanan ekspedisi, seringkali terjadi kendaraan ekspedisi tidak maksimal membawa barang kiriman bahkan pada kondisi tertentu tidak bermuatan atau kosong pada salah satu arah keberangkatan, misalnya truk dalam keadaan penuh barang biasanya membawa karet untuk dijual berangkat dari Sandai menuju 
Kota Pontianak namun pada arah kembali dari Kota Pontianak menuju Sandai dalam keadaan tidak penuh atau kosong. Kondisi ini tidak efisien karena biaya perjalanan akan meningkatkan jika barang yang dibawa sedikit. Sementara itu mungkin ada pihak lain yang memerlukan angkutan tapi tidak mengetahui bahwa adanya truk ekspedisi yang bisa melakukan pengiriman barang ke Pontianak-Sandai. Sehingga dalam kondisi seperti ini sebenarnya truk-truk yang lalu lintas melalui jalur tersebut bisa menerapkan konsep truck sharing.

Konsep truck sharing yang sudah berjalan saat ini masih menggunakan via chat dan telpon untuk mengetahui waktu ketibaan pihak ekspedisi di lokasi penerimaan barang dan untuk menghubungi pihak toko Kota Pontianak, inilah yang membuat ekspedisi pribadi ini kurang efisien dan kurang optimal dalam beroperasi selama ini, pada kasus ekspedisi jalur Kota Pontianak - Sandai.

Dengan adanya jasa ekspedisi ini seperti truk muatan tentu mempermudah para pemilik toko khususnya di Kota Pontianak ini dalam pengiriman barang, dikarenakan bisa dibilang masih kurang informasi jasa ekspedisi jalur Pontianak - Sandai yang diketahui oleh pihak toko, dengan menggunakan pendekatan truck sharing masalah-masalah di atas dapat diselesaikan. Untuk mengetahui lokasi truk ekspedisi tersebut dibutuhkannya alat yang bisa memberikan informasi lokasi secara digital agar bisa diakses oleh aplikasi dengan menggunakan GPS yang ada pada smartphone supir, sehingga dengan menggunakan smartphone supir truk itu sendiri aplikasi juga dapat memberikan notifikasi apabila memang sudah ada orderan pengiriman barang dari Kota Pontianak - Sandai sehingga bisa lebih optimal.

Oleh karena itu muncul suatu ide untuk membuat aplikasi truck sharing pada ekspedisi pengiriman barang jalur Pontianak - Sandai dengan menggunakan pendekatan truck sharing yang membuat pemilik toko dapat terhubung langsung dengan supir truk dengan menyewa truk untuk melakukan pengiriman barang-barang yang berkapasitas besar, dengan menggunakan metode Location Based Service (LBS) sebagai titik lokasi pihak truk yang ditampilkan. Agar menguntungkan dan mempermudah serta mengoptimalkan waktu bagi pihak toko dan truk dalam beroperasi dan dengan Progressive Web App (PWA) aplikasi dapat dibuka disemua perangkat tidak hanya android, IOS dan Windows.

\section{Metodologi}

Pada penelitian ini metodologi penelitian yang digunakan yaitu:

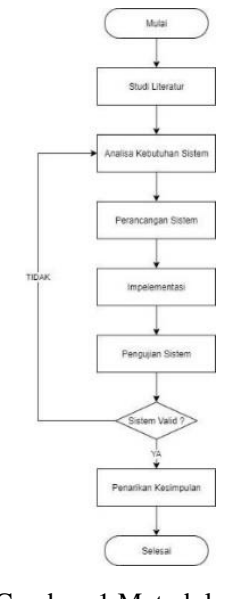

Gambar. 1 Metodologi

\section{A. Studi Literatur}

Dalam tahap studi literatur penelitian ini. bersumber dari buku, website, dan jurnal penelitian. Jurnal penelitian yang digunakan antara lain:

- Nur Dwi Satika. 2014 dengan judul "Sistem informasi Pengiriman Barang berbasis web" [2]

- Edwin Ismail, Agus Sudarsono, Sigit Purwanto (2018) melakukan penelitian dengan judul "Perancangan Sistem Informasi Jasa Pengiriman Berbasis Website Pada PT Perjasa Trans Logistic Pontianak". [3].

- Ainun Hilaliyyah dan Eko Muliyo (2019) dengan judul "Sistem Informasi Ekspedisi Pengiriman Barang Pada Pt Bunga Lintas Cargo" [4].

\section{B. Analisa Kebutuhan}

Pada penelitian ini tahap analisis dilakukan dengan melakukan observasi dan wawancara dari sudut pandang developer yang juga bertindak sebagai pihak ekspedisi. Adapun fokus pada penelitian ini adalah untuk membantu pihak toko menemukan lokasi truk ekspedisi di sekitarnya dan siap membantu mengirimkan barang mereka.

Toko juga wajib menentukan lokasi keberadaan dari bangunan yang dijadikan toko atau ruko, lokasi tersebut didapatkan dari posisi perangkat yang digunakan oleh toko sehingga diperoleh data berupa latitude dan longitude dari posisi toko atau ruko yang akan diolah oleh Google Maps API sehingga akan dapat ditampilkan pada maps pada saat supir akan melakukan penjemputan barang. Aplikasi akan mendeteksi keberadaan posisi toko melalui perangkat yang digunakan, karena aplikasi di bangun menggunakan progressive web app maka akan diterapkan fitur geolocation sehingga toko harus mengaktifkan GPS untuk memberikan data berupa latitude dan longitude yang akan diolah oleh aplikasi, sehingga dapat menampilkan posisi dari keberadaan pengguna.

Supir juga merupakan aktor penting pada penelitian ini, dimana supir juga wajib memiliki akun terlebih dahulu agar tergabung pada aplikasi. Supir wajib mengizin akses lokasi 
keberadaan dan mengaktifkan akun supir dan izinkan notifikasi pada menu dashboard supir, lokasi tersebut juga didapatkan dari posisi perangkat yang digunakan supir sehingga diperoleh data berupa latitude dan longitude dari posisi supir yang akan diolah oleh google maps api sehingga akan dapat tertampilkan pada maps yang dilakukan pencarian oleh toko. Setelah supir berhasil dipilih aplikasi akan memberikan notifikasi ada barang masuk kepada supir penerima, ketika supir yang dipilih menolak maka sistem akan mengarahkan pihak toko untuk mencari kembali supir dengan data lokasi supir terbaru, tapi ketika supir menerima maka supir juga dapat melihat rute lokasi toko pengirim. Apabila lokasi supir yang berpindah, maka aplikasi akan menampilkan lokasi terbaru dari supir saat melakukan pengiriman barang ke tempat tujuan disebut dengan tracking.

Pada proses pencarian supir menerapkan metode LBS pada aplikasi ini, untuk mendapatkan titik koordinat lokasi pengguna dengan memanfaatkan GPS bawaan yang ada pada smartphone pengguna. Pada saat proses cari supir berdasarkan radius yang dipilih oleh toko maka akan muncul lokasi truk yang berada dalam radius tersebut dari yang jarak terdekat sampai yang terjauh, dengan kata lain marker yang berada di luar jangkauan radius toko maka markernya tidak akan tertampilkan. Dengan radius awal sebesar 1000 Meter yang dapat diubah sampai pada radius 10.000 Meter. penerapan metode LBS tersebut menggunakan library yang telah disediakan oleh maps api yang bernama geometry spherical.

Proses penggunaan progressive web app (PWA) disini, untuk membuat sebuah website statis bisa diakses seperti mobile app di semua perangkat, baik itu smartphone, $P C$, laptop, atau tablet. Serta bisa dipasang (Instal) maupun dilepas pada perangkat dan push notification yang dapat memberikan notifikasi kepada pihak supir. Untuk mendapat layanan progressive web app (PWA) disaran menggunakan Google Chrome versi 74 keatas.

\section{Perancangan Sistem}

Pada tahap perancangan sistem, penulis melakukan perancangan terhadap aplikasi yang akan di bangun. Perancangan sistem dalam penelitian ini menggunakan unified modelling language (UML). Unified modelling language (UML) adalah bahasa pemodelan untuk sistem atau perangkat lunak yang berparadigma (berorientasi objek) [5], class diagram sebagai perancangan untuk database penelitian dan arsitektur sistem.

Use Case Diagram bersifat statis, yang memperlihatkan himpunan use case dan aktor-aktor (suatu jenis khusus dari kelas) dan menggambarkan apa saja aktivitas yang dilakukan oleh suatu sistem dari sudut pandang pengamatan luar [6]. Berikut perancangan use case diagram truck sharing app. Dapat dilihat pada gambar 2.

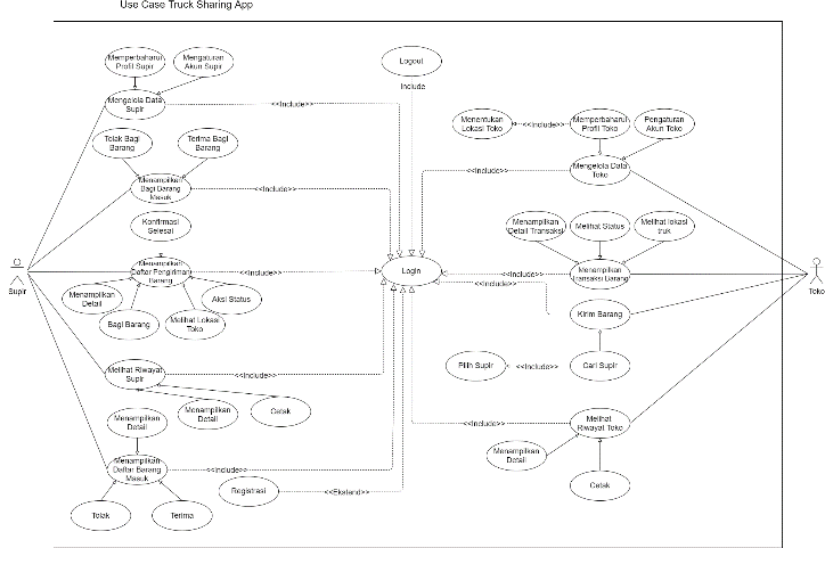

Gambar. 2 Usecase diagram

Class Diagram menggambarkan struktur sistem dari segi pendefinisian kelas - kelas yang akan dibuat untuk membangun sistem [7]. Berikut rancangan dari database penelitian ini. Dapat dilihat pada gambar 3.

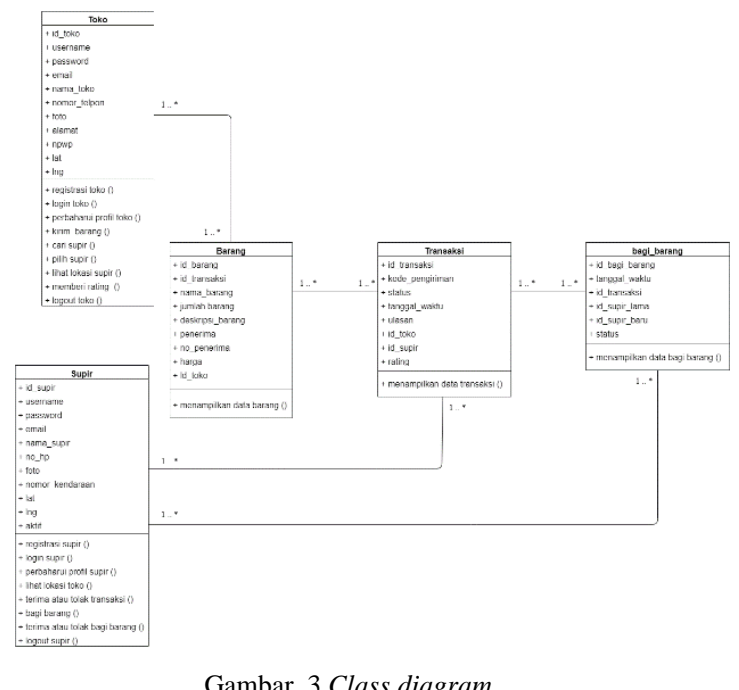

Arsitektur sistem Menggambarkan struktur hubungan antar komponen sistem yang terdiri dari perangkat lunak maupun perangkat keras. Dapat dilihat pada gambar 4

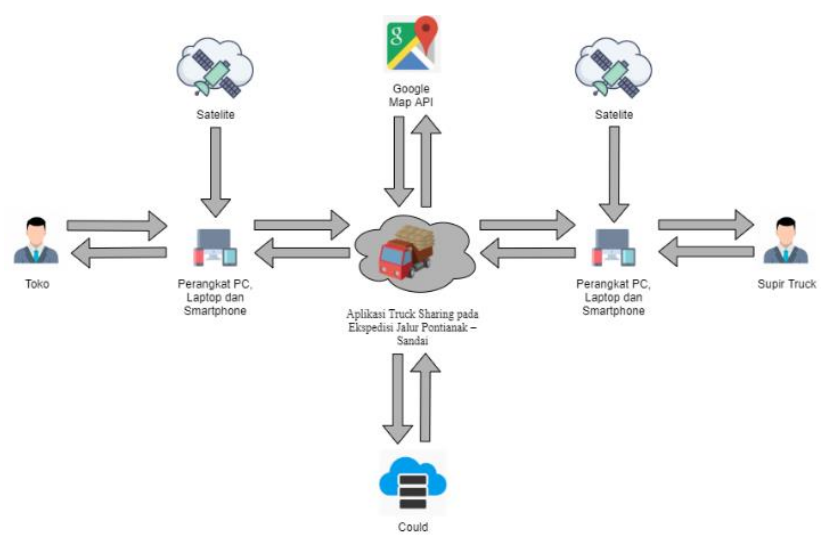

Gambar. 4 Arsitektur sistem 
Toko yang ingin melakukan pencarian lokasi truk dan ingin mengirimkan barang dengan membuka aplikasi (dengan GPS aktif agar posisi di deteksi sistem). Sistem akan mendeteksi posisi pengguna dan melakukan proses perhitungan jarak untuk selanjutnya menampilkan lokasi truk yang ada di sekitarnya berdasarkan radius.

Supir yang menggunakan aplikasi akan melakukan update data berupa status transaksi, tolak barang jika tidak ingin menerima barang dan terima jika akan menerima barang. Jika supir sudah merasa barang kiriman sudah cukup supir dapat merubah status supir menjadi "off" pada menu dashboard supir, informasi lokasi supir tidak akan muncul pada pencarian toko..

\section{Konsep Truck Sharing}

Berbagi truk memungkinkan pemilik truk untuk membantu orang bergerak dan mengirimkan barang-barang besar, cocok untuk anda yang memerlukan bantuan seseorang dengan sebuah truk untuk mengirimkan barang anda. Dengan alih-alih menyewa truk dan melakukan sendiri pekerjaan berat, anda dapat terhubung dengan pemilik truk yang akan membantu anda memuat, mengirim, dan menurunkan barang sesuai permintaan. Pemilik truk dibayar untuk mengangkut kargo dan tenaga mereka sementara pelanggan mendapatkan bantuan dan truk sesuai permintaan, jadi ini merupakan win-win untuk kedua belah pihak [8].

\section{E. Sistem Informasi Geografis}

Sistem informasi geografis adalah sistem yang terdiri dari perangkat keras, perangkat lunak, data, manusia (brainware), organisasi dan lembaga yang digunakan untuk mengumpulkan, menyimpan, menganalisis, dan menyebarkan informasi-informasi mengenai daerah-daerah dipermukaan bumi [9].

\section{F. Global Positioning System (GPS)}

Global Positioning System atau sering disebut GPS adalah sistem untuk menentukan letak di permukaan bumi dengan bantuan penyelarasan (synchronization) sinyal satelit. Sistem ini menggunakan 24 satelit yang mengirimkan sinyal gelombang mikro ke bumi [10].

\section{G. Google Map API}

Google Maps API yang menyediakan beberapa fitur untuk memanipulasi peta, dan menambah konten melalui berbagai jenis service yang dimiliki, serta mengizinkan kepada pengguna untuk membangun aplikasi di dalam websitenya [11].

\section{H. Location Based Service}

Location Based Service (LBS) atau Layanan Berbasis Lokasi merupakan layanan informasi yang memanfaatkan kemampuan untuk menggunakan informasi lokasi dari perangkat bergerak dan dapat diakses dengan perangkat bergerak melalui jaringan telekomunikasi bergerak [12].

\section{Progressive Web App (PWA)}

Progressive Web App (PWA) adalah sebuah website yang dibangun menggunakan teknologi web modern, namun dapat berlaku seperti sebuah mobile app. Pada tahun 2015, Google Engineer Alex Russel dan Frances Berriman memberi istilah progressive web app pada konsep web app yang dapat memberikan user experience dalam keandalan (reliability), kecepatan (speed) dan keterlibatan pengguna (user engagement) [13].

\section{J. Pengujian}

Pengujian merupakan suatu teknik yang digunakan menguji apakah sebuah perangkat lunak yang dihasilkan telah sesuai dengan yang diharapkan atau belum. Pada penelitian ini menggunakan black-box testing pada location-based service (LBS)

1) Pengujian Blackbox: Black Box Testing berfokus pada spesifikasi fungsional dari perangkat lunak [14]. Black Box testing berfokus pada persyaratan fungsional perangkat lunak yang memungkinkan engineers untuk memperoleh set kondisi input yang sepenuhnya akan melaksanakan persyaratan fungsional untuk sebuah program [15].

\section{HASIL DAN PEMBAHASAN}

Jasa ekspedisi yang beroperasi pada jalur Pontianak Sandai yang memanfaatkan truk muatan, pada kasus ini sering kali muatan tidak penuh atau kosong dikarenakan tidak diketahuinya posisi truk tersebut. Dengan aplikasi truck sharing dapat membantu pihak toko mengetahui lokasi truk yang bisa melakukan pengiriman pada saat itu.

\section{A. Penerapan Location Based Service (LBS)}

Pada penelitian ini metode Location Based Service (LBS) berperan untuk menampilkan titik lokasi pengguna toko dan lokasi supir dengan memanfaatkan GPS pada perangkat pengguna berdasarkan radius yang dipilih oleh toko dan sebagai setingan awal dari radius awal adalah $1.000 \mathrm{~m}$ yang tentunya dapat dinaikan sampai pada radius $10.000 \mathrm{~m}$. Dapat dilihat pada gambar 5 .

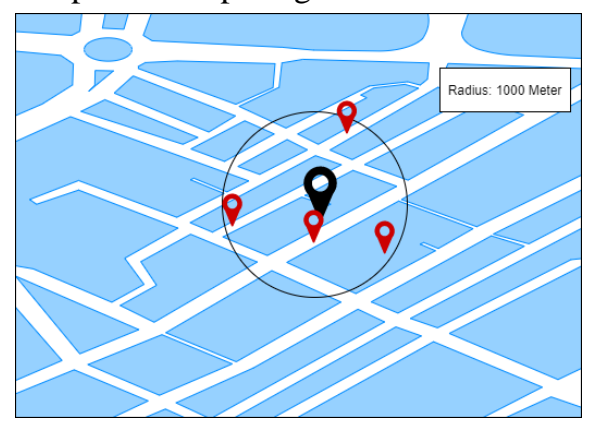

Gambar. 5 Penerapan location based service

Apabila lokasi supir yang berpindah, maka GPS akan bekerja dan aplikasi akan menampilkan lokasi terbaru dari supir kepada toko. Perhitungan jara serta fitur radius memanfaatkan Library Geometry Spherical yang sudah disediakan oleh google. Sehingga lokasi supir yang berada 
di radius yang dipilih dapat ditampilkan. Dapat dilihat pada gambar 6.

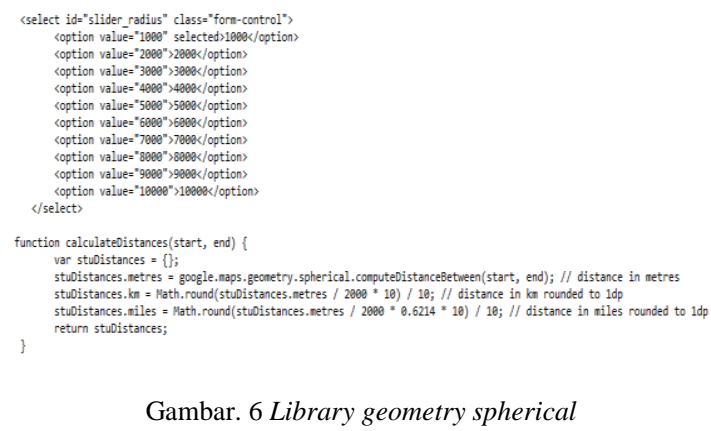

Peran LBS tentu saja tidak akan berjalan apabila tidak ada bentuk tampilan peta virtual, sehingga dibutuhkanlah peran dari Google Maps API untuk menampilkan maps yang akan ditambahkan pada aplikasi yang akan dibuat, sehingga nantinya lokasi supir yang ada pada maps akan menampilkan sebuah marker sehingga dapat ditampilkan kepada pihak toko yang sedang melakukan pencarian.

Penerapan API KEY dari Google Maps tersebut dapat dilihat pada Gambar 7 dibawah ini.

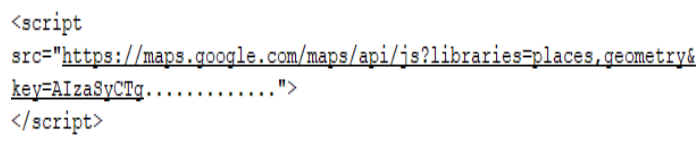

Gambar. 7 Kode program API key

Geolocation merupakan penerapan untuk mendeteksi posisi perangkat pengguna, geolocation mulai digunakan ketika HTML5 muncul, karena aplikasi pencarian lokasi truk dibangun dengan menggunakan Progressive Web App (PWA) yang notabene adalah pengembangan dari sebuah aplikasi berbasis website, maka penentuan posisi perangkat pengguna dilakukan dengan menerapkan Geolocation pada aplikasi yang dibangun.

Adapun cara kerja dari geolocation tersebut adalah mendeteksi posisi perangkat pengguna dengan memanfaatkan Global Positioning System (GPS) yang terdapat pada perangkat yang digunakan, namun apabila perangkat yang digunakan tidak memiliki GPS maka secara otomatis proses pendeteksian posisi perangkat berubah menjadi memanfaatkan alamat IP, RFID, WiFi, MAC Bluetooth, atau ID seluler GSM/CDMA. Penerapan geolocation pada aplikasi yang dibangun dapat dilihat pada Gambar 8 dibawah ini.

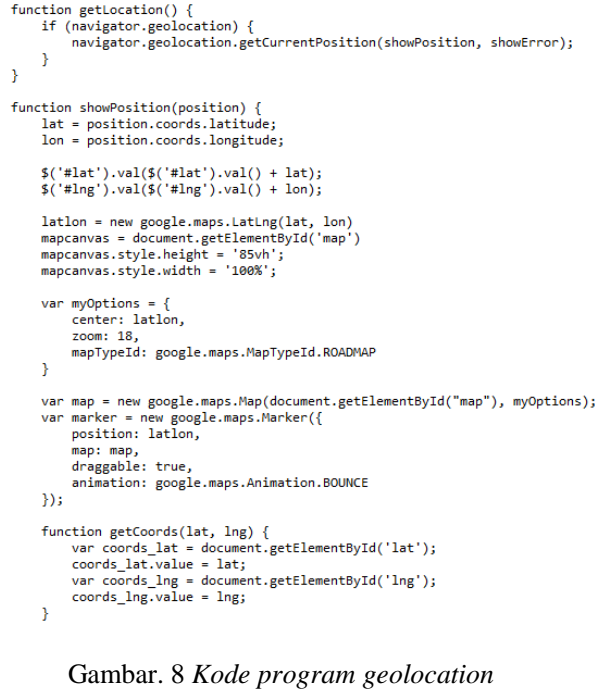

B. Penerapan Progressive Web App (PWA)

Penerapan Progressive Web App (PWA) pada penelitian ini untuk membuat sebuah website statis, yang dibangun menggunakan teknologi web modern, namun dapat berlaku seperti sebuah mobile app pada umumnya.

Pada penelitian ini untuk membuat website menjadi Progressive Web App (PWA) ada beberapa hal yang dipastikan sebagai berikut:

1. Berjalannya add to home screen pada browser chrome, browser edge yang ada pada laptop dan pada browser chrome, samsung browser yang ada pada smartphone. Dapat dilihat pada gambar 9.

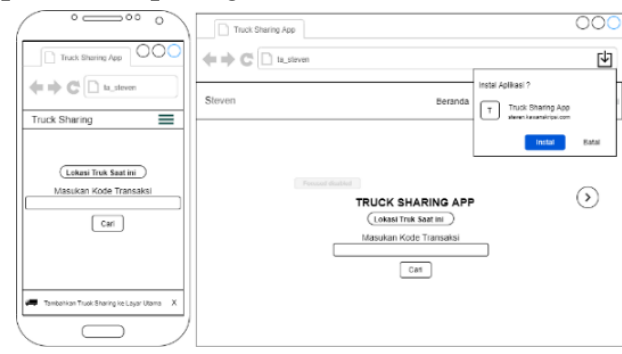

Gambar. 9 Add to home screen

2. Berjalannya yang sudah terpasang Progressive Web App (PWA) Bisa memberikan Push notification yang memungkinkan supir dapat menerima notification barang masuk dengan mengizinkan akses notification. Dapat dilihat pada gambar 10.

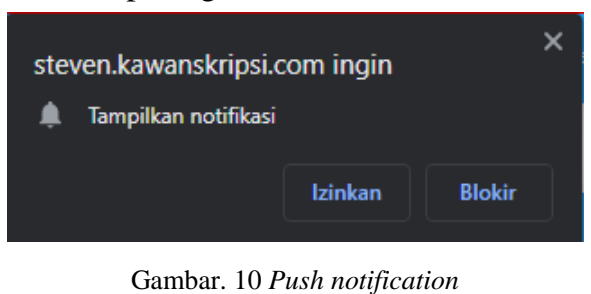

3. Berjalannya aplikasi yang sudah terpasang Progressive Web App (PWA) harus responsif terhadap smartphone, tidak menampilkan link url website pada saat aplikasi 
dibuka dan harus ada icon aplikasi seperti aplikasi native pada umumnya. Dapat dilihat pada gambar 11.

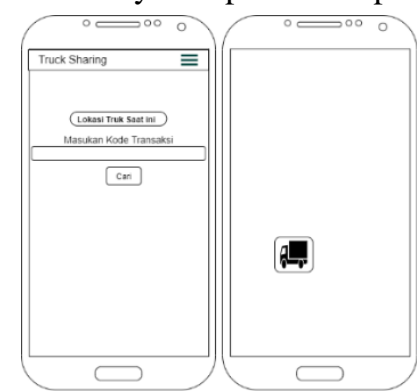

Gambar. 11 Terinstalnya aplikasi setelah menggunakan progressive web app

4. Berjalannya aplikasi yang sudah terpasang Progressive Web App (PWA) dengan menambahkan halaman offline saat aplikasi yang diakses dalam keadaan lost connection dan tidak akan menampilkan dino page saat sebuah website dalam keadaan offline pada umumnya. Dapat dilihat pada gambar 12

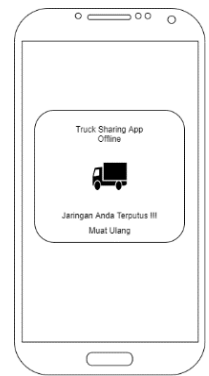

Gambar. 12 Halaman offline

\section{Implementasi}

Implementasi pada aplikasi dengan memberikan tampilan antarmuka yang dibagi menjadi 2 yaitu toko dan supir.

1. Antarmuka aplikasi adalah tampilan awal aplikasi saat pertama kali dibuka, mulai dari login toko, supir dan menu tracking untuk melacak lokasi supir dengan memasukan kode pengiriman dan menu lihat lokasi toko untuk melakukan penitipan barang melalui toko. Dapat dilihat pada gambar 13.

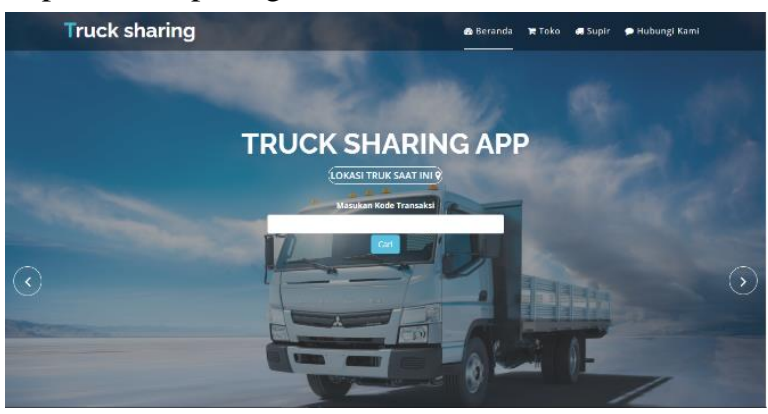

Gambar. 13 Tampilan utama aplikasi

2. Antarmuka pilih supir adalah halaman saat toko sudah mengisi data barang yang akan dikirimkan, kemudian toko akan diminta memilih supir yang berdasarkan radius yang ditentukan oleh toko. Dapat dilihat pada gambar 14.

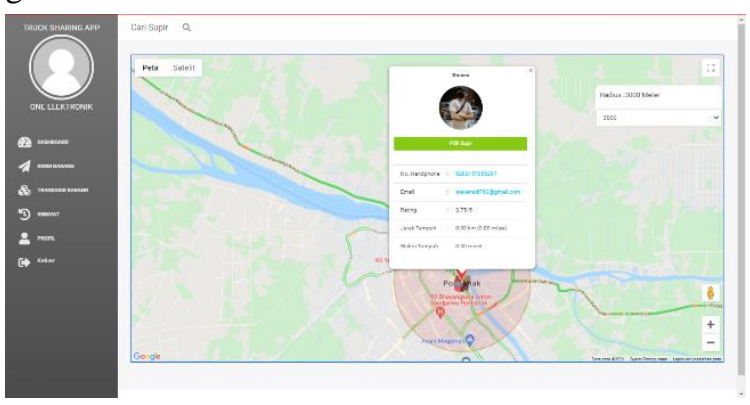

Gambar. 14 Tampilan antarmuka pilih supir

3. Antarmuka transaksi yang menampilkan data-data transaksi yang dilakukan oleh toko seta status-status yang ada pada transaksi mulai dari status diterima, menunggu konfirmasi supir, ditolak, dan status lokasi supir. Dapat dilihat pada gambar 15.
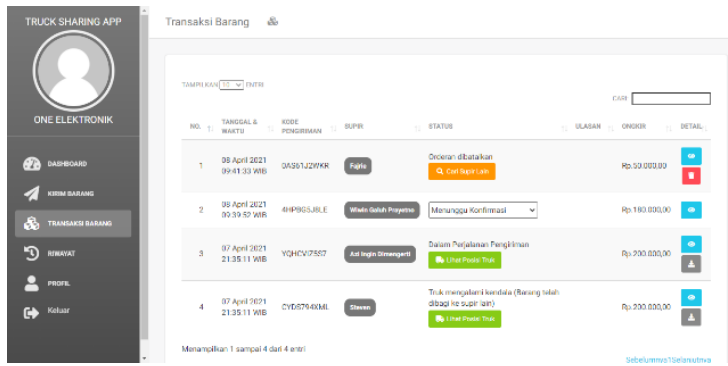

Gambar. 15 Tampilan antarmuka transaksi

4. Antarmuka lihat lokasi supir menampilkan lokasi supir yang sedang melakukan pengiriman. Dapat dilihat pada gambar 16

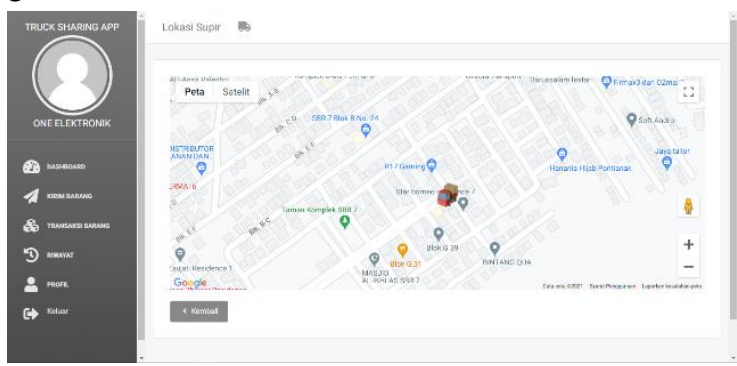

Gambar. 16 Antarmuka lihat lokasi supir

5. Antarmuka supir adalah halaman utama akses supir, pada halaman ini supir memiliki hak akses sebagai penerima barang yang akan dikirimkan sampai pada proses barang tiba ditempat tujuan, dan pada halaman ini supir juga bisa mengaktifkan maupun menonaktifkan akun saat tidak akan menerima barang dan menampilkan lokasi-lokasi toko pengirim. Mengaktifkan dan mengizinkan notifikasi agar mendapat notifikasi pada saat ada barang masuk. Dapat dilihat pada gambar 17. 


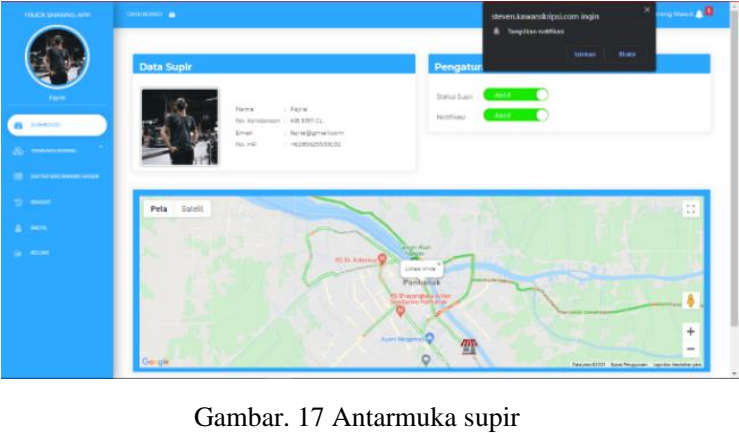

6. Antarmuka daftar barang masuk adalah halaman antarmuka yang menampilkan data daftar barang masuk dari toko yang memilih supir, kemudian supir diminta untuk terima jika ingin menerima barang dan tolak jika ingin menolak. Dapat dilihat pada gambar 18.

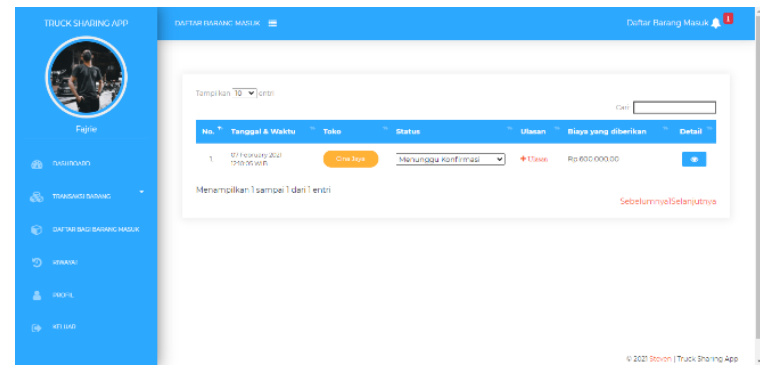

Gambar. 18 Antarmuka daftar barang masuk

7. Antarmuka daftar pengiriman barang adalah halaman antarmuka yang menampilkan data daftar barang yang diterima dan harus dikirimkan dan setelah tiba di tujuan supir dapat mengkonfirmasi transaksi selesai. Dapat dilihat pada gambar 19

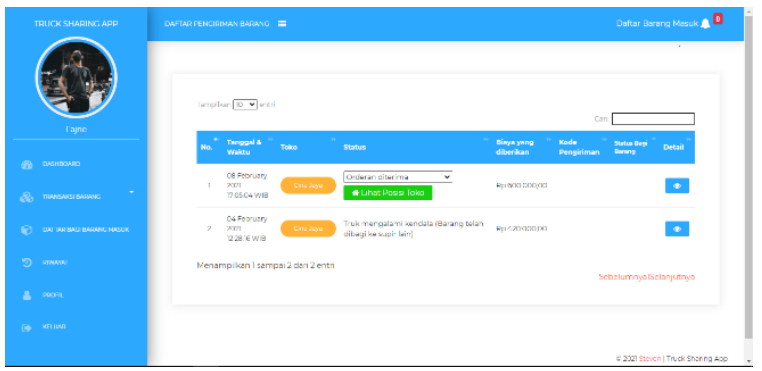

Gambar. 19 Antarmuka daftar barang dalam pengiriman

\section{Hasil Pengujian Black-box pada LBS}

Pengujian Jarak Radius Dari Titik Lokasi Toko, Pada kasus ini fungsi yang akan diuji adalah bagaimana respon aplikasi ketika pengguna melakukan pemilihan radius dari kecil menuju besar, bagaimana titik lokasi yang ditampilkan di dalam jarak radius apakah sudah sesuai dengan yang diharapkan atau belum, titik lokasi yang ditampilkan berupa lokasi truk yang sesuai dengan GPS supir. Titik lokasi pengujian untuk pengguna berada di Jalan Imam Bonjol, GG Kusuma Wijaya, Hasil penelitian dapat dilihat pada tabel I dan gambar 20, 21, 22 dan 23.
TABEL I

PENGUJIAN PENCARIAN BERDASARKAN JARAK RADIUS

\begin{tabular}{|c|c|c|c|c|}
\hline $\begin{array}{l}\text { Kasus } \\
\text { Uji }\end{array}$ & $\begin{array}{l}\text { Bentuk } \\
\text { Penguji } \\
\text { an }\end{array}$ & $\begin{array}{l}\text { Hasil yang } \\
\text { diharapka } \\
\text { n }\end{array}$ & $\begin{array}{l}\text { Hasil } \\
\text { Pengujian }\end{array}$ & $\begin{array}{l}\text { Kesi } \\
\text { mpul } \\
\text { an }\end{array}$ \\
\hline \multirow{4}{*}{$\begin{array}{l}\text { Proses } \\
\text { pencar } \\
\text { ian } \\
\text { berdas } \\
\text { arkan } \\
\text { jarak } \\
\text { radius }\end{array}$} & $\begin{array}{l}\text { Proses } \\
\text { pencarian } \\
\text { berdasark } \\
\text { an jarak } \\
\text { radius }\end{array}$ & $\begin{array}{l}\text { Menampilka } \\
\mathrm{n} \text { titik lokasi } \\
\text { truk di dalam } \\
\text { radius } 1000 \\
\text { meter }\end{array}$ & $\begin{array}{l}\text { Data lokasi } \\
\text { truk yang } \\
\text { muncul } \\
\text { hanya yang } \\
\text { berada di } \\
\text { dalam radius } \\
1000 \text { meter }\end{array}$ & Sesuai \\
\hline & & $\begin{array}{l}\text { Menampilka } \\
\mathrm{n} \text { titik lokasi } \\
\text { truk di dalam } \\
\text { radius } 3000 \\
\text { meter }\end{array}$ & $\begin{array}{l}\text { Data lokasi } \\
\text { truk yang } \\
\text { muncul } \\
\text { hanya yang } \\
\text { berada di } \\
\text { dalam radius } \\
3000 \text { meter }\end{array}$ & Sesuai \\
\hline & & $\begin{array}{l}\text { Menampilka } \\
\mathrm{n} \text { titik lokasi } \\
\text { truk di dalam } \\
\text { radius } 4000 \\
\text { meter }\end{array}$ & $\begin{array}{l}\text { Data lokasi } \\
\text { truk yang } \\
\text { muncul } \\
\text { hanya yang } \\
\text { berada di } \\
\text { dalam radius } \\
4000 \text { meter }\end{array}$ & Sesuai \\
\hline & & $\begin{array}{l}\text { Menampilka } \\
\mathrm{n} \text { titik lokasi } \\
\text { truk di dalam } \\
\text { radius } 9000 \\
\text { meter }\end{array}$ & $\begin{array}{l}\text { Data lokasi } \\
\text { truk yang } \\
\text { muncul } \\
\text { hanya yang } \\
\text { berada di } \\
\text { dalam radius } \\
9000 \text { meter }\end{array}$ & Sesuai \\
\hline
\end{tabular}

1. Hasil pencarian pertama dengan data ketetapan awal tanpa merubah radius, maka aplikasi akan secara otomatis menjangkau pencarian di dalam radius 1000 meter, dan hasil yang didapatkan dari pencarian tersebut adalah hanya ditemukan 1 titik truk dari titik toko yang berada dalam jangkauan radius 1000 meter. Dapat dilihat pada gambar 20.

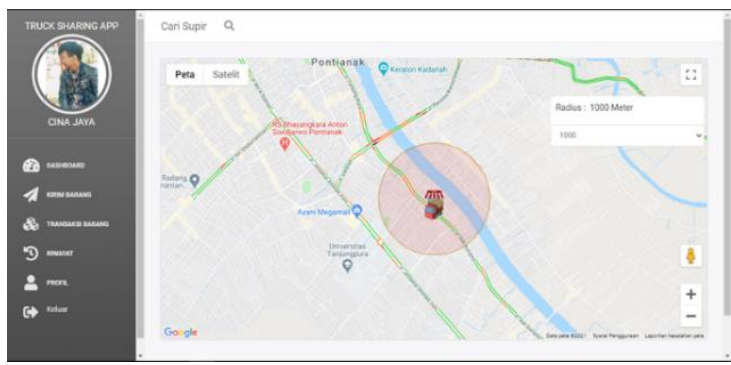

Gambar. 20 Pengujian jangkauan pencarian di radius 1000 meter

2. Hasil pencarian kedua dengan merubah radius menjadi 3000 meter, dan hasil yang didapatkan dari pencarian tersebut adalah ditemukannya 8 titik lokasi truk, dari titik toko yang berada dalam jangkauan radius 3000 meter. Dapat dilihat pada gambar 21 


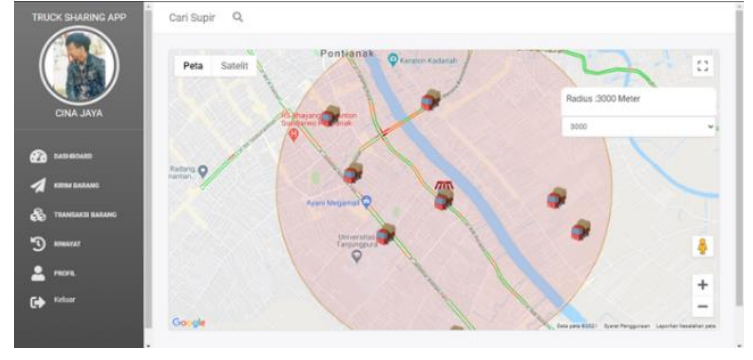

Gambar. 21 Pengujian jangkauan pencarian di radius 3000 meter

3. Hasil pencarian ketiga dengan merubah radius menjadi 4000 meter, dan hasil yang didapatkan dari pencarian tersebut adalah ditemukannya 11 titik lokasi truk, dari titik toko yang berada dalam jangkauan radius 4000 meter. Dapat dilihat pada gambar 22

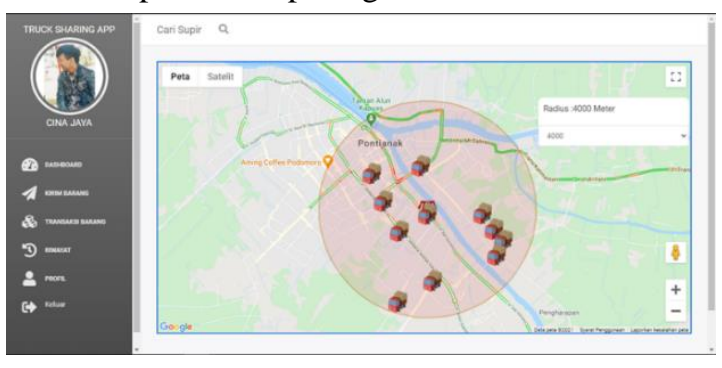

Gambar. 22 Pengujian jangkauan pencarian di radius 4000 mete

4. Hasil pencarian keempat dengan merubah radius menjadi 9000 meter, dan hasil yang didapatkan dari pencarian tersebut adalah ditemukannya 12 titik lokasi truk, dari titik toko yang berada dalam jangkauan radius 9000 meter. Dapat dilihat pada gambar 23.

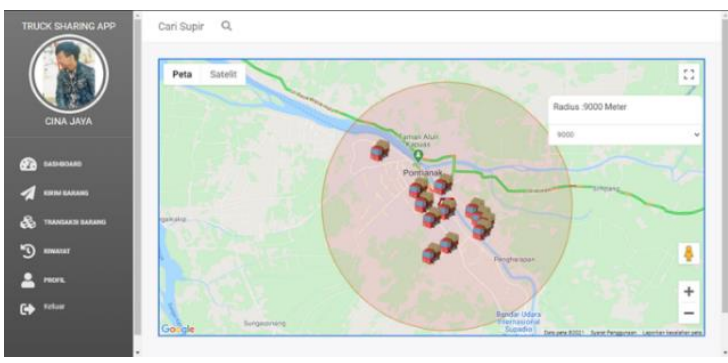

Gambar. 23 Pengujian jangkauan pencarian di radius 9000 meter

\section{KESIMPULAN}

Setelah dilakukan pembuatan aplikasi dengan dilakukannya pengujian dengan metode black-box dengan penerapan metode location-based service maka disimpulkan sebagai berikut:

1. Aplikasi truck sharing telah berhasil dikembangkan dengan menerapkan location based service sehingga dapat menampilkan lokasi truk secara online. Lokasi truk dapat dideteksi dengan menerapkan fungsi geolocation yang merupakan fitur dari HTML5 yang sudah didukung oleh browser-browser terbaru saat ini.

2. Pendeteksian lokasi truk dikelola oleh sistem dan diperlukan oleh pengguna aplikasi (toko atau masyarakat umum) yang memerlukan layanan jasa pengiriman barang menggunakan truk.

3. Konsep truck sharing akan terjadi apabila truk pada jalur Pontianak-Sandai yang kembali menuju Sandai berisi muatan (tidak kosong). Kondisi ini terjadi jika supir truk dan pengguna jasa pengiriman barang dapat dipertemukan oleh aplikasi ini.

4. Aplikasi memiliki fitur rating kepada supir sebagai parameter untuk pengambilan keputusan sederhana bagi toko untuk menentukan jasa supir truk yang akan digunakan untuk pengiriman barangnya.

5. Aplikasi yang dibangun menggunakan progressive web app (PWA) yang tidak ketergantungan pada sistem operasi pada perangkat, melainkan pada browser yang digunakan seperti chrome, edge dan samsung browser untuk menjalankanya.

\section{DAFTAR PUSTAKA}

[1] Philip Kotler. (2001). Manajement pemasaran. Jakarta: Indeks 2008

[2] Satika, N. D. (2014). Sistem Informasi Pengiriman Barang Berbasis Web Dengan Metode Transshipment. Tanjungpinang: Sekolah Tinggi Teknologi Indonesia Tanjung Pinang.

[3] Ismail, E., Sudarsono, A., \& Purwanto, S. (2018). Perancangan Sistem Informasi Jasa Pengiriman Berbasis Website Pada PT Perjasa Translogistic Pontianak. Pontianak: STMIK Pontianak.

[4] Hilaliyyah, A., \& Muliyo, E. (2019). Sistem Informasi Ekspedis Pengiriman Barang Pada Pt Bunga Lintas Cargo. Palembang: STMIK GI MDP Palembang.

[5] Nugroho, A. (2005). Analisis dan Perancangan Sistem Informas dengan Metodologi Berorientasi Objek. Bandung: Informatika.

[6] Widodo, P. P., \& Herlawati. (2011). Menggunakan UML Informatika. Bandung: Informatika.

[7] A. S. Rosa, d. S. (2013). Rekayasa Perangkat Lunak Terstruktur Dan Berorientasi Objek. Bandung: Informatika Bandung.

[8] Park, B. (2017). Apa itu Truck Sharing dan Mengapa Anda Harus Peduli? Dipetik September 23, 2019 , dari https://www.side.cr.

[9] Chrisman. (1997). Menganalisis dan Menyebarkan Informasi Informasi Mengenai Daerah - Daerah Di Permukaan Bumi. Bandung: Informatika.

[10] Kasman, Darma Akhmad. 2013. Kolaborasi Dahsyat ANDROID dengan PHP dan MYSQL. Yogyakarta: Lokomedia.

[11] Kindarto, A. (2008). Asyik Berinternet dengan Beragam Layanan Google. Yogyakarta: Andi.

[12] Steiniger, S., Neun, M., \& Edwardes, A. (2006). Foundations of Location BasedServices. Lecturenotes. Retrieved Juli 20, 2020, from/http://www.spatial.cs.umn.edu/Courses/Fall11/8715/papers/I M7steiniger.pdf.

[13] Santoso, H. (2019). Membangun Aplikasi Mobile dengan PWA (Progressive Web App). Yogyakarta: CV. Lokomedia.

[14] Mustaqbal, M. S., \& Firdaus, R. F. 2015. Pengujian Aplikasi Menggunakan Black Box Testing Boundary Value Analysis. Bandung: Jurnal Ilmiah Teknologi Informasi Terapan

[15] P. R. (2010). Software Engineering: a practitioner's approach McGraw-Hill. New York. 